\title{
New record of Ocythoe tuberculata (Cephalopoda: Ocythoidae) in the North-east Atlantic related to sea warming
}

\author{
Ángela M. Caballero-Alfonso*, Unai Ganzedo-López†, Guzmán Díez-Díez and José J. Castro* \\ *Universidad de Las Palmas de Gran Canaria, Campus Universitario de Tafira, Ciencias Básicas, 35017, Las Palmas, Spain. \\ ${ }^{\dagger}$ AZTI-Tecnalia, Marine Research Division. Txatxarramendi Ugartea z/g 48395, Sukarrieta, Bizkaia. Spain. \\ Corresponding author, e-mail: jcastro@pesca.gi.ulpgc.es
}

The capture of two females of Ocythoe tuberculata during the summer of 2006, in the North-east Atlantic is reported.This pelagic cephalopod species are rare beyond subtropical waters and were caught at the sea surface by two live bait boats. The appearance of this species in the area is related with an anomalous sea warming.

During the summer of 2006, two live specimens of football octopus (Ocythoe tuberculata, Rafinesque, 1814) were captured at the sea surface by live bait boats off the north-west lberian Peninsula, at the northernmost limit of the species distribution in the North Atlantic according to Nesis (1985). The first individual was caught on the 27 June at $41^{\circ} / 42^{\circ} \mathrm{N} 13^{\circ} / 14^{\circ} \mathrm{W}$ (west of Portugal), and the second on the 18 July at $44 / 45^{\circ} \mathrm{N} 14.5^{\circ} / 15.5^{\circ} \mathrm{W}$ (north-west of Spain).

This species is known to be cosmopolitan in tropical and temperate seas (Sweeney et al., 1992; Vechione, 2002), especially in the northern hemisphere (Roper \& Sweeney, 1975). In the Northeast Atlantic, it has been reported off the Azores and Canary archipelagos (Cardoso, I99I) and in the western Mediterranean (Naef, 1923; Petrus \& Pablo, 1993; Ezzeddine-Najai \& El Abed, 200I). However, in the southern hemisphere, this species seems to be less common. In this way, a single catch has been reported off South Africa, associated with a storm in this area (Roper \& Sweeney, 1975), and some others specimens were obtained in New Zealand and Australian waters (O'Shea, 1997; Landsdell \& Young, 2007). The majority of the specimens, however, have been found in the stomach of its predators (swordfish, yellowfin tuna and dolphins), probably associated to their seasonal migrations.

Little is known about the biology and behaviour of Ocythoe tuberculata, except that it has pelagic habits and is found near the surface waters at night (Vechione, 2002). There is a strong sexual dimorphism in this species, where males are usually smaller than $3 \mathrm{~cm}$ in mantle length, and females are significantly larger with mantle lengths that could reach $35 \mathrm{~cm}$ (Roper \& Sweeney, 1975; Cardoso \& Paredes, 1998). Curiously, females of this species are the only known cephalopods with a swimbladder, a feature that makes them able to control their buoyancy (Packard \& Wurtz, 1994), and are the only known cephalopods that give birth to live young that hatch internally (Naef, 1923).

\section{Morphological features}

The measurement of both specimens was taken according to Pickford \& McConnaughey (1949), Thomas (1977), Roper \& Voss (1983) and Clarke (1986). In both females, the pairs of tentacles II and III were shorter than the pairs I and IV. The mantle was muscular and strong. The ventral side was wrinkled, totally covered with hard pyramidal protuberances, but the dorsal side was smooth (Figure la \& b, respectively). The head was more spherical than in other octopus species, and it showed two ventral pores. In Table I the weights and body lengths of both octopus individuals are shown.
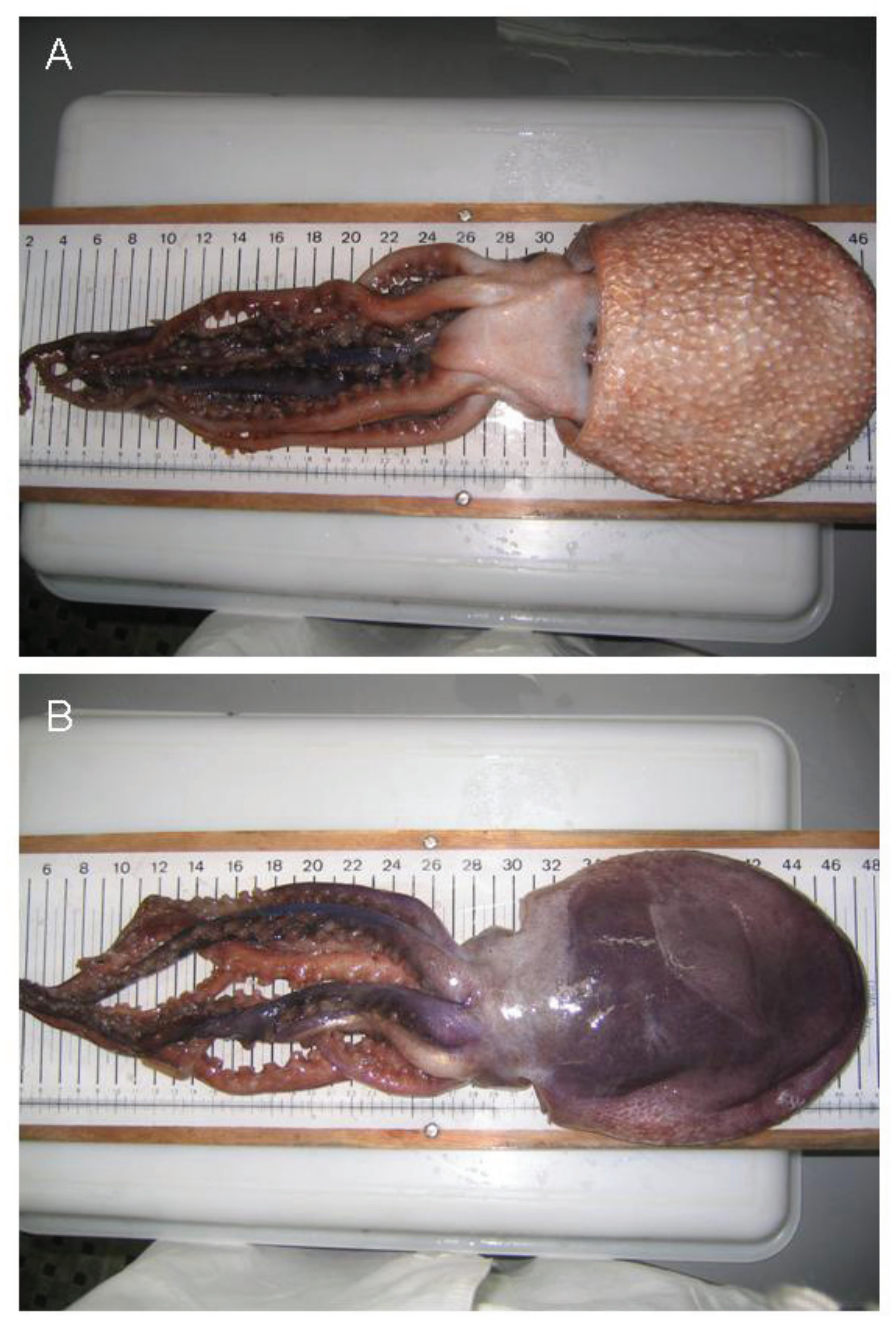

Figure I. Female of Ocythoe tuberculata captured in the North-east Atlantic in June 2006. (A) Ventral view; (B) dorsal view. 


\section{Environmental features}

Although this species has been reported in the Gulf of Biscay in 1936, when Bouxin \& Legendre found one specimen in the stomach content of an albacore (Thunnus alalunga), the presence of live specimens northern of Azores $\left(4 I-45^{\circ} \mathrm{N}\right)$ has not been observed in the scientific literature. It has been normally reported in more temperate waters and probably its capture in this higher latitude area was associated with a seasonal warming process (Figure 2). Furthermore, in June-July of 2006, the sea surface temperature in the west of Portugal and north-west of Spain was $1^{\circ} \mathrm{C}$ warmer than the mean temperature in both months in this area (Figure 3 ). This warming process was also associated with an anomalous peak of jellyfish abundances in June 2006 in the coastal areas of the north-west of Spain (La Voz de Galicia, 7/06/2006).

The anomalous warm summer of 2006 could favour the presence of Ocythoe tuberculata in the oceanic area off the west of Portugal and off the north-west of Spain, and probably associated with the high abundance of jellyfish. Males are sometimes found inhabiting the tests of salps as are young females (Naef, 1923; Okutani \& Osuga, 1986), and both phenomena could be related.

The progressive south-north warming process is a normal annual environmental event which occurs at the end of the spring in the North-east Atlantic. But, this is the first time that the presence of Ocythoe tuberculata has been reported associated to this event, as it has been observed in other oceanic species like Ranzania laevis off the Canary Islands (Castro \& Ramos, 2002). In this way, the capture of football octopus may support the idea that populations can displace temporarily to higher latitudes when anomalous water warming occurs.

Our thanks to the crews of the fishing boats 'Leporre Anaiak' and 'Oskarbi', for making possible these new records.

\section{REFERENCES}

Bouxin, S. \& Legendre, R., 1936. La fauna pelagique de l'Atlantique recueillie dans des estomacs de germons au large de Golfe de Gascogne, II: Cephalopodes. Annales de l'Institut Oceanographique, I6, I-99.

Casey, K. S., 2004. Nighttime-only monthly climatological mean SST (1985200I), standard deviation, and counts based on RSMAS/NODC $4 \mathrm{~km}$ AVHRR Pathfinder version 5.0 sea surface temperature dataset. Silver Spring MD USA: NOAA National Oceanographic Data Center.

Castro, J.J. \&. Ramos, A.G., 2002. The occurrence of Ranzania laevis off the island of Gran Canaria, the Canary Islands, related to sea warming. Journal of Fish Biology, 60, 27I-273.

Cardoso, F., I99I. First record of net collected Ocythoe tuberculata (Cephalopoda: Octopoda) from Peruvian waters. American Malacological Bulletin, 8, I43-I 44.

Cardoso, F. \& Paredes, C., 1998. La familia Ocythoidae (Cephalopoda: Octopoda) en el Perú. Revista Peruana de Biología, 5, 7 pp.

Clarke, M.R., 1986. A handbook for the identification of cephalopod beaks. Oxford: Clarendon Press, 273 pp.

Ezzeddine-Najai, S. \& El Abed, A., 200I. Sur una espèce nouvelle dans la faune teuthologique de Tunisie: Ocytehoe tuberculata rafinesque, I8I4 (Cephalopoda, octopoda).www.instm.rnrt.tn/dwl/pub8_200I.pdf

Landsdell, M. \& Young, J., 2007. Pelagic cephalopods from eastern Australia: species composition, horizontal and vertical distribution determined from the diets of pelagic fishes. Review of Fish Biology and Fisheries, I7, $125-138$.

La Voz de Galicia, 2006. La ola de calor multiplica los ataques de medusas a los bañistas de Samil. 7th June 2006. (http://www.lavozdegalicia.es/hemeroteca/ 2006/06/07/484/243.shtml).

Naef, A., I 923. Die cephalopoden. Fauna e Flora de Golfo di Napoli. Monograph 35, I (2), I 50-863.

Nesis, K.N., 1985. Oceanic cephalopod molluscs: distribution, life form and evolution. Moscow: Nauka Press. [In Russian.]

Okutani, T, \& Osuga, K., 1994. A peculiar nesting behavior of Ocythoe tuberculata in the test of a gigantic salp, Tethys vagina. Venus, 45, 67-69. 
O'Shea, S., 1997. Status of three Octopoda recorded from New Zealand, based on beaks recovered from longdistance foraging marine predators. New Zealand Journal of Zoology, 24, 265-266.

Packard, A. \& Wurtz, M., 1994. An octopus, Ocythoe, with a swimbladder and triple jets. Philosophical Transactions of the Royal Society of London B, 344, 26I-275.

Petrus, J.L. \& de Pablo, F., 1993. Nota sobre la captura d'Ocythoe tuberculata Rafinesque, I8I4 (Cephalopoda: Ocythoidae) en aigues de Menorca. Bolleti de la Societat d'Historia Natural de les Balears, 36, 62-63.

Pickford, G. E. \& McConnaughey, B.H., 1949.The Octopus bimaculatus problem: a study in sibling species. Bulletin of the Bingham Oceanographic Collection, 1 2, I-66.

Roper, C. \& Sweeney, M.J., 1975. The pelagic Octopod Ocythoe tuberculatta Rafinesque, 18I4. Bulletin of the American Malacological Union, Inc.: $21-28$.

Roper, C.F.E. \& Voss, G.L., 1983. Guidelines for taxonomic descriptions of cephalopod species. Memoirs of the National Museum of Victoria, 44, 49-63.

Sweeney, M.J., Roper, C.F.E., Mangold, K.M., Clarke \& M.R., Boletzky,S. (Eds.), 1992. “Larval”and juvenile cephalopods: a manual for their identification, vol. 513. Smithsonian Contributions to Zoology, 232 pp.

Thomas, R.F., 1977. Systematics, distribution and biology of cephalopocis of the genus Tremoctopus (Octopoda: Tremoctopodidae). Bulletin of Marine Science, 27, 353-392.

Vechione, M. 2002. Cephalopods. In The living marine resources of the Western Central Atlantic,Vol. I (K.E. Carpenter, Ed.). FAO: Rome. 